Viewpoints and Letters to the Editor are published in Hort- comments on matters of concern to horticulturists. These are Science to provide members of the American Society for Hor- not statements of official Society policy nor do they necessarticultural Science an opportunity to share their experiences and ily reflect the views of a majority of the Society's members.

\title{
The Decade of the 1980s for Iron Nutrition and Interactions in Plants
}

\author{
Arthur Wallace \\ Laboratory of Biomedical and Environmental Sciences, University of California-Los Angeles, \\ Los Angeles, CA 90024-1786
}

As a result of a display of interdisciplinary interest on $\mathrm{Fe}$ at an international symposium on trace elements at UCLA in 1979, a symposium was sponsored on Fe by the Benson Institute at Brigham Young Univ., Provo, Utah, in 1981., The 82 papers were published in the Journal of Plant Nutrition (Vol. 5, 1982). Disciplines represented included horticulture, agronomy, genetics, soil science, plant breeding, plant physiology, plant biochemistry, microbiology, genetics, plant pathology, and animal science.

Four equally successful -symposia followed: Logan, Utah (1983), with 78 papers in the Journal of Plant Nutrition (vol. 7, 1984); Lincoln, Neb. (1985), with 71 papers in the Journal of Plant Nutrition (vol. 9, 1984); Albuquerque, N.M. (1987), with 90 papers in the Journal of Plant Nutrition (vol. 11, 1988); Jerusalem, Israel (1989), with 80 papers to appear in Plant and Soil, and also in a symposium book. In July 1991, the sixth meeting will be held in Logan, at Utah State Univ., with Gene W. Miller of the Biology Dept as general chairman.

More progress was perhaps made in the 1980 s on understanding and management of $\mathrm{Fe}$ chlorosis $\mathrm{m}$ plants than during the previous 150 years since it became known that Fe deficiency was involved in the chlorosis. For many years, there was a general attitude that $\mathrm{Fe}$ chlorosis was almost impossible to correct or too expensive to do so and extremely difficult to understand. Even the advances made with metal chelates in the 1950s and 1960s did little to change these attitudes. Now, new tools are available to cope with Fe chlorosis.

In the 1980s, a solid foundation was prepared for use of plant breeding and biotechnology to develop plant cultivars with improved resistance to $\mathrm{Fe}$ chlorosis. A more complete, but as yet not full, understanding

Received for publication 26 Feb. 1990. The cost of publishing this paper was defrayed in part by the payment of page charges. Under postal regulations, this paper therefore must be hereby marked advertisenrent solely to indicate this fact.

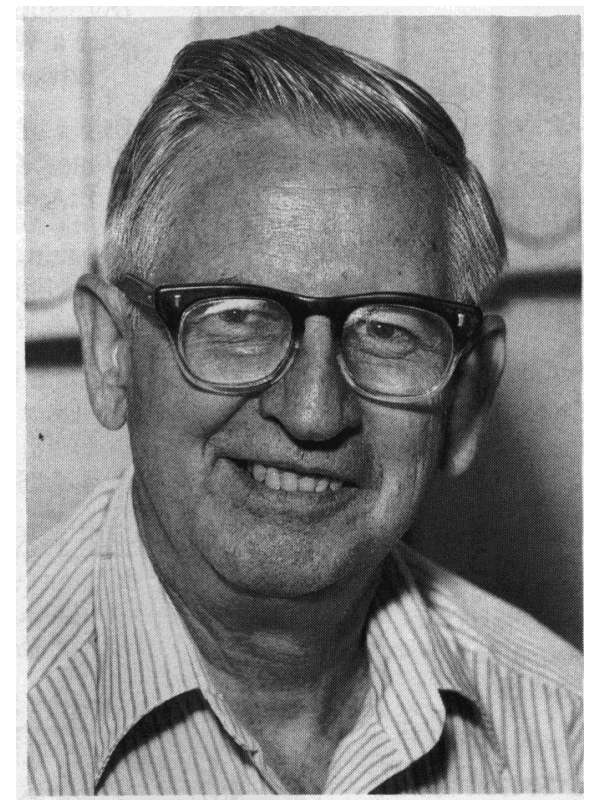

Arthur Wallace

was developed of the mechanisms of Fe mobilization and uptake by plants, The mechanisms differ greatly according to species and cultivar. Although obviously not this simple, plants have so far been divided into two groups according to their ability to obtain $\mathrm{Fe}$ when it is poorly available. Roots of Strategy 1 plants elaborate reducing reactions, develop specialized cells that release protons and sometimes reductants. Roots of Strategy 2 plants, grasses in particular, produce and excrete phytosiderophores, which chelate Fe, and the whole molecule is available, especially to the plants that produce them. $\mathrm{Fe}^{2+}$ is essential for Strategy 1 and $\mathrm{Fe}^{3+}$ for Strategy 2 plants.

Microorganisms produce siderophores, some of which can make Fe available to higher plants; their direct role in practical control of $\mathrm{Fe}$ chlorosis and in bioengineering has promise.

There is a wide range of variability within cultivars of a given species for both Strategy
1 and Strategy 2 plants, and some Strategy 2 plants seem to have some characteristics of Strategy 1 plants. The variability means that some germnplasm has a high degree of Fe efficiency that can be used in breeding programs. Rootstock for trees and shrubs are included for which there is much opportunity for advancement. There is much variability among the microorganisms also, and many different kinds of siderophores are involved.

Information concerning the specialized reactions involving the rhizosphere leads the way to improved methods for control of $\mathrm{Fe}$ chlorosis. Speciation of metals has been effectively identified with computer technology. Synthetic chelating agents can be more effectively used; soil $\mathrm{pH}$ control in microsites can be an efficient procedure for improved Fe uptake; Fe in organic amendments in microsites can become an effective control measure; fertilizer sources can be better chosen to maximize Fe efficiency; more precise diagnosis is possible.

New knowledge now makes it possible to quite effectively control the available levels of the micronutrients $\mathrm{Fe}, \mathrm{Zn}, \mathrm{Mn}$, and $\mathrm{Cu}$ in hydroponic media so that neither deficiency nor toxicity result.

Even though the 1980s saw tremendous strides in understanding of $\mathrm{Fe}$, there is much yet that can be done. The findings need to be translated into cultivars that use Fe efficiently; new microorganisms can become a means for control of $\mathrm{Fe}$ chlorosis; waste organic matter can be better used with Fe plus acidifiers and certain fertilizers to solve $\mathrm{Fe}$ problems; the wide differences between socalled Strategy 1 and Strategy 2 plants can be considered in control procedures; the role of the strategies on the nutrition of other elements, particularly $\mathrm{P}, \mathrm{Zn}, \mathrm{Mn}$, and $\mathrm{Cu}$, needs better elucidation.

Horticulturists need to become more involved in these matters. There can be many rewards when researchers from several disciplines and from several nations work closely together for a number of years in an area of common interest. The decade of the 1980s saw this accomplished for $\mathrm{Fe}$ nutrition of plants, and the efforts will continue through the 1990s. 